\title{
Boy Sexual Victimization: Characteristics of Family Configuration and of the Offender
}

\author{
Maria Aparecida Penso ${ }^{1, *}$ (D), Maria Inês Gandolfo Conceição ${ }^{2}$ (D), Liana Fortunato $\operatorname{Costa}^{2}$ (D), \\ Amanda Pinheiro Said ${ }^{2,3}$ (D) \& Lúcia Cavalcanti de Albuquerque Williams ${ }^{4}$ (D) \\ ${ }^{1}$ Universidade Católica de Brasília (UCB), Taguatinga, DF, Brasil \\ ${ }^{2}$ Universidade de Brasília (UnB), Brasília, DF, Brasil \\ ${ }^{3}$ Secretaria de Saúde do Distrito Federal, Brasília, DF, Brasil \\ ${ }^{4}$ Universidade Federal de São Carlos (UFSCar), São Carlos, SP, Brasil
}

\begin{abstract}
The study aims to identify the family profile of boys who were victims of sexual abuse and of their offenders. Intake documents from a health facility in the capital of Brazil, consisting of 35 cases from that institution over a period of 13 years were analyzed. Analysis of quantitative data with descriptive statistics for the following categories involved: age of family members; relatives living in the same household; education and occupation of family members; who did the victim reside with; victim's main caretaker; gender and relationship of victim and offender. The families were economically deprived with low educational background, and in lack of community institutional support. As a result, they took protection initiatives by themselves, delegating childcare to immediate or extended relatives, a strategy which increased vulnerability

KEYWORDS: sexual abuse, male victims of sexual abuse, analysis of intake, child maltreatment
\end{abstract}

\section{Abuso Sexual de Meninos: Características da Configuração Familiar e do Ofensor}

\begin{abstract}
RESUMO - O texto tem por objetivo identificar o perfil familiar de vítimas de abuso sexual de sexo masculino e seus ofensores. Trata-se de pesquisa documental realizada em um serviço de saúde no Distrito Federal, Brasil, em 35 prontuários inscritos nesta instituição ao longo de 13 anos. A análise dos dados quantitativos utilizou estatísticas descritivas para as seguintes categorias analisadas: idade dos familiares; parentes residindo na casa; escolaridade e ocupação dos familiares; com quem a vítima reside/adulto responsável pela vítima; sexo e parentesco do ofensor. As famílias apresentam carência econômica, baixa escolaridade, falta de apoio institucional comunitário. Assim, mostram iniciativas individualizadas de proteção, delegando o cuidado a parentes imediatos, ou relativamente próximos, que acabam mais por vulnerabilizar do que por proteger.
\end{abstract}

PALAVRAS-CHAVE: abuso sexual, meninos vítimas de abuso sexual, pesquisa documental, violência intrafamiliar

The objective of this paper is to identify the profile of families of male victims of sexual abuse who were referred to a healthcare service with the goal of discussing the profile of the family of boys who have been sexually victimized in the Brazilian mid-west, particularly within the Federal District. Little is known regarding sexual victimization suffered by boys in Brazil, as well as their family relations (Baptista,
Franca, Costa, \& Brito, 2008; Hohendorff, Habigzang, \& Koller, 2012; Lauritsen \& Carbone-Lopez, 2011). Sexual abuse suffered by boys remains more obscure than the abuse suffered by girls (Scrandis \& Watt, 2014; Valente, 2005), and this is also the case of the sexual abuse suffered in childhood by adult men (Easton, Coohey, Rhodes, \& Moorthy, 2013; Hershkowitz, 2014; O’Leary, Easton, \&

*E-mail: mariaaparecidapenso@gmail.com

- Submetido: 08/01/2017; Aceito: 26/08/2019. 
Gould, 2017). According to statistical data published by the Centro de Referência para Violência Sexual (CEREVS) or the Sexual Violence Referral Center of the Child and Youth Family Court of Brazil's Federal District (Vara da Infância e da Adolescência [VIJ/DF], 2010), among the different modalities of violence, family violence is recognized as the one that occurs most regularly when compared to violence by non-family members. Similarly, sexual violence by family members has higher prevalence in comparison with non-family sexual violence.

The prevalence of sexual abuse among this specific population is still unknown in Brazil. A study by Serafim, Saffi, Achá and Barros (2011), regarding demographic data and emotional and behavioral aspects of a sample of 205 children victims of sexual abuse who were undergoing psychological and psychiatric evaluation in São Paulo, revealed that in the age group ranging from $6-14$ years of age, $63.4 \%$ were girls and $36.6 \%$ were boys. The study found that the age group of boys with the highest risk of sexual abuse was found between 3-6 years of age. Research on the characterization of sexual abuse in children reported through the Sentinel Program confirmed the predominance of sexual abuse among girls (85\%); findings that are in agreement with both the Brazilian and international literature consulted (for example, Easton et al., 2013; Guimarães \& Vilela, 2011, respectively). Brazilian regional studies (Miranda, 2010; Pinho, 2012), conducted among the population assisted by the Federal District's social welfare department also found a higher prevalence of sexual abuse among girls.

A study conducted by Costa et al. (2018) identified the profile of the sexually victimized boy in a healthcare institution of the Brazilian mid-west: higher prevalence of sexual victimization at six years of age; average time interval between the occurrence of sexual victimization and the arrival at the institution equal to 2 - 6 months; most victims' level of schooling fell within an elementary level, within the first and fourth grades (63\%); in $40 \%$ of the cases the victim lived with both parents, and in $48.6 \%$ of the cases siblings were present in the home. Regarding income, in $24 \%$ of the cases the family lived on an income between 1 - 5 minimum wages, $23 \%$ with 3 minimum wages, and $53 \%$ with more than five minimum wages. In $54 \%$ of cases the sexual abuse was perpetrated by a family member, and in $43 \%$ by non-family members.

\section{ENVIRONMENTAL CHARACTERISTICS OF THE SEXUALLY ABUSED BOY}

Studies with male adults who were victimized during childhood indicate characteristics that could be identified as risk factors for such form of victimization: living with a single mother; or living without parents; having parents who remarried or who are separated; having parents who are alcohol-dependent or who exhibit criminal behavior; black ethnicity; and belonging to underprivileged social classes (O’Leary et al, 2017; Rodgers \& McGuire, 2012).

Same-sex violence usually involves a male offending parent or relative and the victimized child, but the victim's mother can also perpetrate such violence. Recent studies (Setubal, Wolff, Stroher, Vieira, \& Costa, 2019; Willis \& Levenson, 2016) discuss sexual violence perpetrated by women, a phenomenon that is also engulfed by various gender biases and stereotypes. Apart from mothers, young female babysitters were also mentioned (Cortoni, Hanson, $\&$ Coache, 2010; Valente, 2005), as well as teachers. In a review of international studies, Hohendorff et al. (2012) found that the offender of boys was male in $53 \%$ to $94 \%$ of cases. Most offenders (98\%) claimed to be heterosexual, and more than $90 \%$ of adolescents or young adults victims declared being offended by men. Approximately $54 \%$ to $89 \%$ of perpetrators were non-family members, and $21 \%$ to $40 \%$ were not known to the victim (Hohendorff et al., 2012).

Studies point out that the reasons behind the silencing of sexual abuse in male victims are gender-related issues (Baptista et al., 2008; Lauritsen \& Carbone-Lopez, 2011; O'Leary et al., 2017). Victims of sexual violence in general, and boys in particular do not usually talk about the subject (Scrandis \& Watt, 2014; Valente, 2005), and reasons presented by boys aged between 7 and 13 years for not reporting sexual violence were fear of their parental reactions, the possible rupture in the family unit, as well as fear of aggressor's reaction.

\section{FAMILY RELATIONSHIPS OF THE SEXUALLY ABUSED BOY}

The study of family organization as a factor of protection or vulnerability in the sexual abuse of children has been increasingly prioritized (Hollist, Hughes, \& Schaible, 2009; Lauritsen, \& Carbone-Lopez, 2011; Rodgers \& McGuire, 2012; Worley et al., 2011). The process of reporting male sexual abuse is closely linked to the family reactions, and depends on whether or not the family is open to such disclosure (Scrandis \& Watt, 2014; Valente, 2005). Consequences of sexual violence may include: problems of a physical nature (trauma, sexually transmitted diseases) (short term); emotional (fear, anxiety, depression) (short and medium term); behavioral (social isolation, inappropriate sexual behavior, and cognitive impairment) (short, medium and long term) (Scrandis \& Watt, 2014; Valente, 2005). The 
repercussions of sexual violence can also affect the victim's family; with the disclosure of sexual violence suffered by the boy, family members may react with panic, anger, depression, crying, and also doubts concerning the boy's sexuality, difficulties in setting boundaries for the child, and fear that the child will become a sexual offender (Hohendorff et al., 2012). Rodgers and McGuire (2012) and Lauritsen and Carbone-Lopez (2011) place the study of the family as essential while surveying the scope of the child's risk and protection factors, before and after victimization.

The influence of gender on the process of reporting and intervention of male child sexual abuse is recognized and considered to be an important aspect (Leach, Stewart, \& Smalbone, 2016; Pincolini \& Hutz, 2014). For instance, few men refer to what happened to them as rape. Ultimately, the family is seen by researchers as having a fundamental role in the protective circle (Bogaerts, Buschman, Kunst, $\&$ Winkel, 2010; Valente, 2005). With regard to the sexual victimization of boys, it is believed that an understanding of the dynamic aspects that are brought forth by the family configuration may compose a more explanatory picture of relationships within the family and provide insights for a deeper understanding of the relationship between sexual abuse and family interaction. The main question that is posed regards the protective factors that family configuration offers, as well as knowing the quality of family interactions and the victim's surrounding environments (Hollist et al., 2009; Lauritsen \& Carbone-Lopez, 2011; Rodgers \& McGuire, 2012; Worley et al., 2011).

\section{METHOD}

The present study examined intake health records in an attempt to characterize the family configuration of the sexually abused male child as well as his offender. The study complements information in regards to the characterization of the sexually abused boy pertaining to data collected in the same institution (Costa et al., 2018), and intends to broaden the understanding of the victim's family environment. The previous study (Costa et al., 2018) attempted to describe the socio-demographic profile of the sexually abused boy (gender, age, education, socioeconomic income), identifying variables such as the relationship between the victim and the perpetrator, place in which the sexual abuse took place, and family structure involved. The study sought to gain access to details regarding variables concerning the sexually abused boy's family context by identifying the age of family members, presence of relatives residing in the same house, who the victim resided with, who was the adult responsible for the victim, level of education and occupation of family members, as well as the offender's gender and kinship. Both studies were carried out in the same institution.

\section{Context}

The institution where the records of sexually abused boys were consulted is a Mental Health Center that is part of the Child and Adolescent Protection Network treating victims and perpetrators of sexual abuse under the Ministry of Health of Brazil's Federal District's Government.

\section{Sample}

The health records examined were derived from services provided over a span of more than 13 years (from 2002 to 2014) involving 51 cases of male children (up to 12 years old) with allegations of being sexually victimized. The inclusion criterion for a case to be part of the study was the fact that the records included the transcript of an initial interview with the victim. In all, 35 records met the inclusion criteria and were analyzed. The initial interviews were conducted by psychologists or social workers of the institution, which regularly met the families who arrived at the institution spontaneously or by referral. The interview was carried in the presence of an adult responsible for the child. Each interview lasted an average of one hour, and was guided by the following protocol points information: demographics (name, date of birth, age, education, family income); father, mother, siblings; family income, religion; the sexual incident that occurred; the perpetrator of violence; details of the notification and other associated records, and consequences from the violence experienced.

\section{Data Collection Procedure}

An Excel spreadsheet was constructed with data related to the family characterization, containing the following information: age of father, mother, brothers, sisters, family members' levels of education, occupation of mother and father, who resided in the household, occupation of any other adults; if perpetrator was a family member or not. Each case record was reviewed by two researchers to ensure greater level of quality in record keeping.

\section{Data Analysis}

The analysis of quantitative data employed descriptive statistics (frequencies, percentages, mean and standard deviations) and prioritized the following aspects: (1) age of the victim's father, mother, brothers and sisters; (2) the 
presence of relatives residing in the house; (3) level of schooling of family members; (4) father's and mother's occupation; (5) who the victim resided with / adult responsible for the victim; (6) the offender's gender; (7) kinship / relationship with the offender.

\section{Ethical Aspects}

The project was approved by the Institution Review Board, (Ministry of Health from the Federal District) under ruling number 331/09.

\section{RESULTS AND DISCUSSION}

\section{Age of Fathers and Mothers}

Twenty-seven cases containing the information regarding the fathers were identified, and in these cases the fathers were on average 36 years old. A total of 33 reports with information concerning the mother were identified and the average maternal age was of 32 years. Fathers' ages ranged from 24 to 49 years of age, whereas mothers' ages ranged from 26 to 46 years of age. Table 1 presents the percentage of fathers, mothers, brothers, and sisters of victims according to their age group. In order to calculate the percentages of fathers and mothers in each one of the age groups the total number of records containing paternal $(\mathrm{N}=27)$ and maternal $(\mathrm{N}=33)$ information was used. For calculating the percentage of brothers and sisters in each age group, the total number of brothers $(\mathrm{N}=32)$ and sisters $(\mathrm{N}=27)$ identified in the 15 records that contained such information was used.

Data regarding variables such as the age of fathers and mothers were not identified in other studies regarding the epidemiology of the sexually victimized boy, in the Brazilian literature (Baptista et al., 2008; Hohendorff et al., 2012; Guimarães \& Vilela 2011; Serafim et al., 2011), and international literature (Bogaerts et al., 2010; Scrandis \& Watt, 2014; Valente, 2005). Mothers and fathers had a similar age mean; they were both within active working ages, which possibly meant that the couple left home for work on a regular basis and the children were left under the care of other people that may or not be relatives, or even teenagers. There were no cases of adolescent mothers. The study of environmental conditions surrounding children (including boys who are victims of sexual violence) has become particularly interested in three aspects: interpersonal violence, family relationships and poverty (Rodgers \& McGuire, 2012). There is yet another aspect that is the insertion of the child and family within the community, considering the quality of the interactions that occur in the neighborhood in which the child has access (Lauritsen \& Carbone-Lopez, 2011). These contexts are seen in terms of their quality as behavior predictors that affect individual or social vulnerability.

\section{Age of Siblings}

There were 15 case records with information regarding siblings (female and male), and in 20 case records there was no such information. In $40 \%$ of cases there was no record of age of brothers in the record and in $13 \%$ of cases there was no record of the age of sisters. The average age of the brothers was 8.4 years, ranging from 4 months to 23 years of age, while the average age of sisters was 8.4 years, ranging from 9 months to 22 years of age.

A total of 35 families were surveyed; 32 brothers and 27 sisters were identified and were distributed into categories such as siblings from the same father and mother, from

Table 1

Percentage of fathers, mothers, brothers and sisters to each age range

\begin{tabular}{lcccc}
\hline Age (years) & Father & Mother & Brother & Sister \\
\hline 0 a 5 & & & $37,5 \%$ & $37 \%$ \\
6 a 10 & & & $28,1 \%$ & $25,9 \%$ \\
11 a 15 & & & $9,8 \%$ & $22,2 \%$ \\
16 a 20 & & & $6,3 \%$ & $11,1 \%$ \\
21 a 25 & $3,6 \%$ & $42,4 \%$ & & $3,7 \%$ \\
26 a 30 & $17,9 \%$ & $36,4 \%$ & & \\
31 a 35 & $21,4 \%$ & $12,1 \%$ & & \\
36 a 40 & $21,4 \%$ & $6,1 \%$ & & \\
41 a 45 & $25 \%$ & $3 \%$ & & \\
46 a 50 & $7,1 \%$ & & & \\
Deceased & $3,6 \%$ & & & \\
\hline
\end{tabular}


different fathers, and from different mothers. From the sample, in 13 of the 15 cases in which siblings were present the age of at least one of the siblings ranged from 0 to 10 years, which is precisely the spectrum wherein lies the highest levels of incidence of sexual violence against boys, as already indicated. The presence of violence in family relationships is a strong predictor of future victimization of children or adolescents, especially when it comes to sexual violence (Turner, Shattuck, Finkelhor, \& Hamby, 2016). The fact that there could be many family members gravitating around the children, in addition to the father and mother, who usually work away from home, may raise questions on whom is indeed responsible for caring for the children.

On the other hand, families living in violent neighborhoods, with poor social support, where children have little adult supervision, face increased family stress which may lead parents to present coercive behaviors that in turn build a vicious circle of violence and insufficient protection of the child (American Psychology Association [APA], 2015; Finkelhor, Ormrod, Turner, \& Holt, 2009). Authors who study the immediate environment surrounding children who are victims or perpetrators of sexual abuse have focused on the knowledge regarding the influence of poverty and violent family relationships on the existence or not of sexual violence in the family. These studies show that family relationships without intimate partner violence, high levels of parental affection, and closeness between parents and their children are more important to creating a protective environment than poverty per se (Rodgers \& McGuire, 2012; Worley et al., 2011). The present study argues that the presence of numerous family members under the same roof in a poor environment without community support, may lead families to a situation where they do not have access to adequate caretakers who may be held responsible for the safety of the children. A study on violence and socioeconomic status (APA, 2015) points out that knowledge of risk of community violence requires a clear understanding of the implications of unemployment, poverty, vulnerability, reduced opportunities for social ascension, and participation in family-related decisions, as well as poor housing conditions and lack of access to community support services, as is observed in the community of the families from the present study.

\section{Presence of Relatives Residing in the House}

Records demonstrated that relatives (father, mother, siblings, aunts and uncles, grandparents, stepparents, and cousins) were residing in the house of 33 of the 35 families that make up the sample. Of the 22 cases in which the mother was responsible for the victim, she shared this responsibility exclusively with the father in 14 of cases, with her son's

Table 2

Percentage of family members responsible for the victims and respective educational level.

\begin{tabular}{|c|c|c|c|c|c|c|c|c|c|c|c|c|}
\hline & Father & Mother & Brother & Sister & $\begin{array}{l}\text { Grand- } \\
\text { father }\end{array}$ & $\begin{array}{l}\text { Grand- } \\
\text { mother }\end{array}$ & Cousin & Uncle & Aunt & $\begin{array}{l}\text { Step- } \\
\text { father }\end{array}$ & Nanny & Total \\
\hline \multicolumn{13}{|c|}{ Relationship with the victim } \\
\hline Living together & $11,1 \%$ & $21,4 \%$ & $25,4 \%$ & $18,3 \%$ & $3,2 \%$ & $7,1 \%$ & $2,4 \%$ & $3,2 \%$ & $2,4 \%$ & $4,8 \%$ & $0,8 \%$ & $100 \%$ \\
\hline Guardian & $25,9 \%$ & $40,7 \%$ & & & $5,6 \%$ & $16,7 \%$ & & & & $11,1 \%$ & & $100 \%$ \\
\hline \multicolumn{13}{|l|}{ Education } \\
\hline Pre-school & & & & $1,5 \%$ & & & & & & & & $1,5 \%$ \\
\hline Kindergarten & & & $1,5 \%$ & $1,5 \%$ & & & & & & & & $3,0 \%$ \\
\hline $\begin{array}{l}\text { Elementary School } \\
\text { (incomplete) }\end{array}$ & $7,5 \%$ & $6,0 \%$ & $13,4 \%$ & $11,9 \%$ & $1,5 \%$ & & $1,5 \%$ & & & $3,0 \%$ & & $44,8 \%$ \\
\hline $\begin{array}{l}\text { Elementary School } \\
\text { (complete) }\end{array}$ & & & & & $1,5 \%$ & & & & $1,5 \%$ & & & $3,0 \%$ \\
\hline $\begin{array}{l}\text { High School } \\
\text { (incomplete) }\end{array}$ & & $3,0 \%$ & $3,0 \%$ & $1,5 \%$ & & & & & & & & $7,5 \%$ \\
\hline $\begin{array}{l}\text { High School } \\
\text { (complete) }\end{array}$ & $7,5 \%$ & $16,4 \%$ & & & & $1,5 \%$ & & $1,5 \%$ & & $3,0 \%$ & & $29,9 \%$ \\
\hline $\begin{array}{l}\text { University } \\
\text { (incomplete) }\end{array}$ & & $1,5 \%$ & & & & $1,5 \%$ & & $1,5 \%$ & $1,5 \%$ & & & $6,0 \%$ \\
\hline Illiterate & & $1,5 \%$ & & & & $1,5 \%$ & & $1,5 \%$ & & & & $4,5 \%$ \\
\hline
\end{tabular}


stepfather in six cases, in four cases she shared responsibility with her own mother and in one case the mother had sole responsibility for the child. The maternal grandmother, in turn, was the sole caretaker for the child in two cases, and in three others she shared responsibility with her husband, who was also the child's grandfather. The detailed description of family members residing with the child and guardians, as well as their levels of schooling is displayed in Table 2.

In a study carried out in an administrative region of the Federal District (which represents a similar reality to the one of this sample), Pinho (2012) found, among the records of a public social assistance institution, that in 40 of the intake records surveyed concerning sexually abused boys and girls there was reference made to the presence of 22 brothers and sisters under 18 , as well as 7 related children in the same house. This is a facet of reality that deserves attention, as it is directly linked to the family configuration that take place when there is a presence of an expressive number of children and affiliated family members, resulting in difficulties in offering protection to all members. While comparing epidemiological results of child sexual abuse in China and several other countries, Finkelhor, Ji, Mikton and Dunne (2013), found lower prevalence results for girls and even fewer for boys in the first country. These low rates may be associated with higher levels of family vigilance over girls, low divorce rates, with children being surrounded by higher levels of protection, not being left alone in private places with other adults, the collective virtues that are emphasized, and the fact that usually families in China are small. The authors concluded that supervision of children might inhibit abuse. In the present study when emphasis is given to a diversity of brothers and sisters present in the family environment, the underlying hypothesis is that this represents a factor of vulnerability, which may impair the family's ability to offer and or guarantee protection for all of the children under their responsibility.

Pinho (2012) and Miranda (2010), in studies that explored realities close to the present sample, point out the relevance of children moving around and about the house in association with the fact that the houses are organized within plots of land that house several branches of the family. The protection offered to children is distributed among people that co-inhabit the space, whether they are related or not (Costa et al., 2014).

\section{Family Members' Level of Schooling}

Considering the total number of family members, the level of schooling with highest concentration lied within incomplete elementary schooling. In a study conducted in one of the administrative regions that is also present in the present sample, Pinho (2012) also found mostly low-income families with low levels of education.
It is not common to find descriptions of the educational level in families with sexual abuse victims in the literature, particularly in the international papers that were perused (Bogaerts et al., 2010; Lauritsen et al., 2011; Scrandis \& Watt, 2014; Valente, 2005), perhaps because illiteracy is still prevalent and typical in low and middle income-countries. Rodgers and McGuire (2012) are an exception in this regard since they clearly indicate an association between the context of material poverty, which is associated with low education, as a risk factor for the emergence of inappropriate sexual behavior.

Two aspects stand out: adults with little education (often the children's caregivers) and children without access to day care centers, who are therefore required to be under the responsibility of adults belonging to the extended family or others who are linked to the child by neighborhood-related bonds. The first aspect calls attention to adapt the written material that is created by children's protections services to raise awareness on child sexual abuse (Cordeiro, 2006), as they fail to make the information accessible to individuals who are unable to read.

The second aspect stems from the knowledge that families employ direct relatives (siblings), or extended family members (cousins, uncles) as caregivers of children (Costa et al., 2014), which is associated with the low number of day care spaces offered to the vulnerable population, as shown in the statistics by the Federal District (FD). The FD has 740,095 children according to the FD Portrait of Childhood and Adolescence (Retrato da Criança e do Adolescente, (2012). Of this total, 39.49\% are considered to be "extremely poor" according to the categories listed by the Development and Planning Company of the Federal District (CODEPLAN - Companhia de Desenvolvimento e Planejamento do Distrito Federal), and only $23.20 \%$ of children between 0-3 years of age are enrolled in day care centers or schools, whereas $80.66 \%$ of children aged $4-5$ are in this same condition. The FD has 27 Early Childhood Education Centers and 60 day care centers which can take in up to 35,621 children between the ages $3-5$, and 14,900 children between the ages of 0 - 5 years, making up the total of children in day care centers. The vacancy deficit acknowledged by the district's government (Distrito Federal, 2015) is of 24,250. In 2015 the government stated its intention to offering a thousand new vacancies for that year.

The lack of day care centers for childcare for working parents is corroborated by qualitative and regional studies. Costa et al. (2014) conducted a qualitative research by interviewing family members of seven adolescent sexual offenders who abused seven victims from the family ( 5 sisters, 1 niece, 1 cousin). The authors pointed out that the adolescents had been in charge of baby-sitting their siblings while the parents were at work, preparing meals and bathing them, in addition to performing household chores. In addition, these families also took care of children from the extended family who stayed during the day or resided with them permanently. 
Thus it is vital to recognize that violence and the family's socioeconomic status (which reflect and reproduce the community's conditions) have an intense and profound relationship. The broader social context, and the quality of the social network to which the family relies upon for support are involved in the protection offered to children. The resources that foster protection and aid families are relative to the resources of the social class to which they belong. If the family has access to healthcare, financial stability, an income that provides for their basic needs, their social problems are mitigated. The opposite is also true. Overall, a low socioeconomic status is associated with low levels of schooling, material poverty and poor health (APA, 2015; Spilbury \& Korbin, 2013). The emphasis given in this paper to housing conditions involving large numbers of residents is part of the characteristics that define material impoverishment, low levels of schooling, and as a consequence the presence of low-skilled jobs due to a lack of access to formal jobs.

\section{Occupation of the Father and the Mother}

Out of the 35 intake records, 30 were included in this analysis and are described in Table 3. Miranda (2010), conducted a survey in an area also included in the present sample with similar results: mothers worked as kitchen assistants, nannies, general service assistants, and most of them $(34.61 \%)$ worked as house maids, with low salaries (average income between $1-1.5$ the minimum wage); they remained away from home for long periods of time during the day, and commuted for about two hours between place of residence and their place of work. The fathers worked as policemen, and gas station attendants and earned slightly more than the mothers (between 1.5 - 2 minimum wages). Research conducted by Pinho (2012) analyzing 40 records of a social service institution exemplified the same reality in which both parents worked in low-paying activities and had only and elementary education. The combination of low levels of education, low salaries, the need to receive help from relatives in caring for the children, and having to stay away from home throughout the day, are elements that increase the vulnerability of the potential victims, since these are conditions that weaken parent-child bonds (Bogaerts et al., 2010; Finkelhor et al., 2013; Worley et al., 2011).

\section{Who the Victim Resided with / Adult Responsible for the Victim}

Throughout the 35 records that were surveyed, many different family configurations were observed which included different people and roles: parents, grandfathers and grandmothers, uncles and aunts, cousins, and stepparents (see Table 2). The data contradicted the idea that children who are under their mother's sole responsibility could be more vulnerable to sexual victimization (Scrandis \& Watt, 2014), as in the present study most victimized boys lived with both their mother and their father.

The study of sexual violence, whether focusing on the offender or the victim, has directed the attention to the quality of family relationships. Interpersonal/interparental violence, low levels of the child's perception of parental affection, the degree of closeness between the parents and their children are risk factors for the emergence of child sexual abuse (Lauritsen \& Carbone-Lopez, 2011; Rodgers $\&$ McGuire, 2012; Worley et al, 2011). In the research conducted by Pinho (2012), nine family members were responsible for the children while both parents worked. The findings regarding who the victim resides with reinforces a position who deconstructs the idea that a working mother is associated to higher risk for child sexual abuse (Santos \& Pelisoli, 2008), as in the present study as well as in Pinho's 2012 both the father and the mother remained away from home during their workday.

\section{Perpetrator's Gender}

Forty-seven offenders were identified; in two cases the records did not contain any information regarding gender. Of the total number of perpetrators, 38 were male $(80.8 \%)$, and seven victimizations were committed by females $(19.2 \%)$. Two of the participants were victimized by both males and females, and each member of a pair of twins was victimized by four male adolescents in school.

In spite of the small sample of the present research, the high proportion of female sexual offenders found is unusual. Various authors (Cauffman, 2008; Cortoni et al., 2010; Strickland, 2008) agree that sexual violence perpetrated by female adults or adolescents is significantly lower than the

Table 3

Percentage of parents according to the occupation.

\begin{tabular}{|c|c|c|c|c|c|c|c|c|c|}
\hline \multicolumn{10}{|c|}{ Occupation } \\
\hline & $\begin{array}{c}\text { Self- } \\
\text { employed }\end{array}$ & $\begin{array}{c}\text { Security } \\
\text { Guard }\end{array}$ & $\begin{array}{c}\text { Food } \\
\text { business }\end{array}$ & Commerce & $\begin{array}{c}\begin{array}{c}\text { Other } \\
\text { services }\end{array} \\
\end{array}$ & Student & Teacher & $\begin{array}{c}\text { Clerical } \\
\text { Ministry }\end{array}$ & Unemployed \\
\hline Father & $21,4 \%$ & $21,4 \%$ & $14,3 \%$ & $14,3 \%$ & $17,9 \%$ & & $7,1 \%$ & & $3,6 \%$ \\
\hline Mother & $13,6 \%$ & & $9,1 \%$ & $31,8 \%$ & $18,2 \%$ & $4,5 \%$ & $9,1 \%$ & $9,1 \%$ & $4,5 \%$ \\
\hline
\end{tabular}


one perpetrated by male individuals. In a Brazilian research conducted with a sample of 229 cases, Pincolini and Hutz (2014) found that female offenders were represented in only $5 \%$ of cases. Hohendorff et al. (2012) cite studies that indicate the prevalence of sexual abuse by females at around $2 \%$, in relation to the population of sexually abused children. In another Brazilian study, Miranda (2010) did not identify the presence of female offenders in a sample containing 30 records. Furthermore, the final data for 2009 from the Federal District's Youth Court (VIJ, 2009) demonstrated that there was no indication of sexual victimization by a female offender in 173 cases, highlighting the fact that the mother was not a sexual offender for that year, as Lauritsen and Carbone-Lopez (2011) argue that the study of sexual abuse needs to be discussed in terms of gender variables that may prevent one from recognizing the extent to which such a phenomenon may occur due to a preconceived idea that women will always play a protective and caring role towards children.

On the other hand, qualitative work such as Etherington's (1999) sheds light on how children suffer when victimized by a female perpetrator in a position of responsibility, as is the case of a mother. In a study with men who were sexually victimized by their mothers in childhood, Etherington (1999) identified consequences of such experience mainly on the socialization process, construction of defense mechanisms for coping with this situation, and the distortion that occurred over the sense care and protection. Apart from the fact that the violence suffered is incomprehensible to the child, there are serious consequences that take place through a feeling of humiliation by the boy as they may see themselves in a situation where they are forced to play the role of the mother's "male counterpart". The damage suffered may be more severe, and may interfere in the expression of their sexuality when the mother is the sexual offensor.

Most female sex offenders are babysitters as indicated by Scrandis and Watt (2014) and Valente (2005). In fact, for the present sample, two of the offenders had been employed for taking care of the child; and the others were: a maternal aunt, a sister and a neighbor, that is, women in close proximity to the victim. Again, it should be emphasized that an aspect that masks the unawareness surrounding sexual abuse perpetrated by females regards cultural prejudices that always see women as maternal and protective (Strickland, 2008).

The high number of female offenders present in this paper is intriguing and opens doors for further questioning of a subject that is still obscure and overlooked. The prevalence of sexual abuse perpetrated by women is still unknown, and in a US survey conducted by Strickland (2008) involving 130 incarcerated women ( 60 sexual offenders and 70 non-sexual offenders), points to a prevalence of $4 \%$ of cases while quoting several different studies in an attempt to delineate such data. Something else that stands out in the present study is the fact the two boys were victimized by both males and females. Strickland (2008) points out that only $1 \%$ of girls are victimized by female offenders, while $18 \%$ of victims are molested by both sexes.

A study conducted by Mascarenhas et al. (2010), with 518 children victims of violence who were treated through public emergency services in several different Brazilian capitals, is regarded as an example of the lower proportion of sexual abuse committed by women when compared to men; 15 (sexual abuse perpetrated by a male) to 1 (sexual abuse perpetrated by a female). The authors cite a 2011 survey of high school students conducted by the Youth Risk Behavioral Surveillance System, Scrandis and Watt (2014), showing that $4.5 \%$ of boys claimed to have been forced to have sexual intercourse with men. Once again, it is possible consider gender-related issues in such a discussion, as the masking of the presence of violence as a result of considering a boy's early sexual activity.

\section{Kinship / Relationship with the Perpetrator}

A total of 47 offenders were identified from the 35 cases that were analyzed. The categories "cousin" and "classmates" involved the greatest number of victimizations (9). The latter includes the eight fellow classmates who victimized the twins (Table 4).

A regional survey conducted by Miranda (2010), using a sample that contained 30 files, reported that the stepfather was the perpetrator in $44 \%$ of cases, the father in $25 \%$ of the cases, and the uncle, cousin and grandfather in less than 5\% of the cases. In a descriptive survey regarding the profile of emergency care services in several Brazilian municipal areas, involving children under the age of ten who were victims of violence, Mascarenhas et al. (2010) indicated a questionable percentage of $3.5 \%$ for sexual assault perpetrated by family members from a total of 518 records listed over a time span of 30 days between years 2006 and 2007. The largest entry for this sample was $55 \%$ for home aggressions, and within such category $67.4 \%$ was related to physical aggression.

In a study conducted in the United States of America (Easton et al., 2013) reports the presence of $11 \%$ of interfamilial sexual abuse without specifying in which manner victim and perpetrator were related; in $61 \%$ of the same sample, the sexual abuse was perpetrated by a priest. Presently such data seems to be absent from Brazilian epidemiological studies, as there are no publications regarding sexual abuse committed by religious authorities.

Regarding the analyzed sample, there is a discrepancy with the literature regarding kinship: there were nine victimizations committed by cousins. Two regional surveys (Miranda, 2010; Childhood and Youth Court [VIJ], 2009), 


\begin{tabular}{lcc}
\hline & Male & Sexual offender \\
& 9 & Female \\
\hline Cousin & 9 & \\
Classmate & 4 & 1 \\
Uncle/aunt & 3 & 1 \\
Father & 8 & \\
Known adolescent & 2 & \\
Neighbour & 1 & 1 \\
Stepfather & 1 & 2 \\
Brother/sister & & 2 \\
Nanny & 1 & 7 \\
Unknown & 38 & \\
Total & & \\
\hline
\end{tabular}

involving sexually victimized girls and boys, agreed that the father and stepfather were the most frequent sexual perpetrators, and cousins were identified as a sexual perpetrator in less than $5 \%$ of cases. On the other hand, Baptista et al. (2008) indicated that in their sample the abuses were committed, mostly by stepfathers, fathers, and brothers-in-law; in only $3 \%$ of cases was the abuse perpetrated by cousins.

The variables "Age of brothers", "Age of sisters" and "Presence of relatives residing in the house" made it possible to draw a relationship between the number of people residing in the same house or lot, relatives, with the presence of numerous teenagers, which were brothers, sisters or relatives. These teenagers were called upon to take care of the children due to the lack of an educational system that can take the child in full time and also due to the absence of day care centers. These aspects should be viewed as concentric circles, which compose a meshwork of vulnerabilities that increase the potential for victimization. Costa et al. (2014) discuss the role change these adolescents are submitted to on a daily basis by being placed in a hierarchical position above the children by day, and being repositioned as an equal to children by night when the parents come home from work, and are therefore challenged to rebuild fraternal bonds with their brothers.

\section{FINAL CONSIDERATIONS}

It is necessary to interpret the profile of families of sexually abused boys in a contextualized manner since the present sample was characterized by low income. In addition to the family's economic distress, their low level of schooling, and difficulties faced to access resources from their community, such as day care centers and full-time schools, had an impact on their own strategies in terms of protecting children, in the sense that they had to rely on immediate or extended family members for care, which made the children more vulnerable.
A limitation of the present study is associated with the challenge of collecting data from records that were often incomplete. Notwithstanding, some factors make present results valuable: access to a population and subject matter difficult to access, data collection from official documents (records from an intake institution), and scarcity of published studies emphasizing family-related aspects of boys victims of sexual abuse. 


\section{REFERENCES}

American Psychology Association. (2015). Violence \& Socioeconomics Status. Retrieved from http://www.apa.org/ $\mathrm{pi} / \mathrm{ses} /$ resources/publications/factsheet-violence.aspx. Acesso em 16/09/2019.

Baptista, R. S., Franca, I. S. X., Costa, C. M. P., \& Brito, V. R. S. (2008). Caracterização do abuso sexual em crianças e adolescentes notificados em um Programa Sentinela. Acta Paulista de Enfermagem, 21(4), 602-608.

Bogaerts, S., Buschman, J., Kunst, M. J. J., \& Winkel, F. W. (2010). Intra- and extra-familial child molestation and personality disorders. International Journal of Offender Therapy and Comparative Criminology, 54(4), 478-493. doi: 10.1177/0306624X09334519

Cauffman, E. (2008). Understanding the female offender. The Future of Children, 18(2), 119-142. doi: 10.1353/foc.0.0015

Cordeiro, F. A. (2006). Aprendendo a prevenir. Orientações para o combate ao abuso sexual de crianças e adolescentes. Brasília: Promotoria de Justiça de Defesa da Infância e da Juventude. Retrieved from http://www.mpdft.mp.br/portal/pdf/ imprensa/cartilhas/cartilha_aprendendo_prevenir.pdf Acesso em 16/09/2019.

Cortoni, F., Hanson, R. K., \& Coache, M-E. (2010). The recidivism rates of female sexual offenders are low: A meta-analysis. Sexual Abuse. A Journal of Research and Treatment, 22(4), 387-401. doi: 10.1177/1079063210372142

Costa, L. F., Penso, M. A., Conceição, M. I. G., Junqueira, E. L., Meneses, F. F. F., \& Stroher, L. M. C. (2014). Violências e Violências: As relações familiares do adolescente ofensor sexual. In L. C. A. Williams, \& L. F. Habigzang (Eds.), Crianças e adolescentes vítimas de violência. Prevenção, avaliação e intervenção (pp. 125-142). Curitiba: Juruá.

Costa, L. F., Penso, M. A., Conceição, M. I. G., Rocha, B. S., \& Williams, L. C. A. (2018). El abuso sexual de niños en el Distrito Federal, Brasil: Un análisis documental de la atención en las instituciones sanitarias. Acta Psiquiátrica y Psicológica de América Latina, 64(1), 64-71.

Distrito Federal. (2015). Rollemberg anuncia 1008 vagas em creches públicas em 17/03/2015. Retrieved from http://g1.globo.com/ distrito-federal/noticia/2015/03/rollemberg-anuncia-1008vagas-em-creches-publicas.html

Easton, S. D., Coohey, C., Rhodes, A. M., \& Moorthy, M. V. (2013). Posttraumatic growth among men with histories of child sexual abuse. Child Maltreatment, 18(4), 1-10. doi: $10.1177 / 1077559513503037$

Etherington, K. (1999). Maternal sexual abuse of males. Child Abuse Review, 6, 107-117. doi: 10.1002/(SICI)10990852(199705)6:2<107::AID-CAR301>3.0.CO;2-I

Finkelhor, D., Ormrod, R. K., Turner, H. A., \& Holt, M. (2009). Pathways to poly-victimzation. Child Maltreatment, 14(4), 316-329. doi: 10.1177/1077559509347012

Finkelhor, D., Ji, K., Mikton, C., \& Dunne, M. (2013). Explaining lower rates of sexual abuse in China. Child Abuse \& Neglect, 37, 852-860. doi: 10.1016/j.chiabu.2013.07.006

Guimarães, J. A. T. L., \& Vilela, W. V. (2011). Características de violência física e sexual contra crianças e adolescentes atendidos no IML de Maceió, Alagoas, Brasil. Cadernos de Saúde Pública, 27(8), 1647-1653.

Hershkowitz, I. (2014). Sexually intrusive behavior among alleged csa male victims: A prospective study. Sexual Abuse: A Journal of Research and Treatment, 26(3), 291-305. doi: $10.1177 / 1079063213486937$

Hohendorff, J., Habigzang, L. E., \& Koller, S. H. (2012). Violência sexual contra meninos: Dados epidemiológicos, características e consequências. Psicologia USP, 23, 395-415.
Hollist, D. R., Hughes, L. A., \& Schaible, L. M. (2009). Adolescent Maltreatment, negative emotion, and delinquency: An Assessment of General Strain Theory and Family-based Strain. Journal of Criminal Justice, 37(4), 379-387. doi: https://doi. org/10.1016/j.jcrimjus.2009.06.005

Lauritsen, J. L., \& Carbone-Lopez, K. (2011). Gender differences in risk factors for violent victimization: An examination of individual-, family-, and community-level predictors. Journal of Research in Crime and Delinquency, 48(4), 538-565. 10.1177/0022427810395356

Leach, C., Stewart, A., \& Smalbone, S. (2016). Testing the sexually abused - sexual abuser hypothesis: A prospective study longitudinal birth cohort study. Child Abuse \& Neglect, 51, 144-153. doi: 10.1016/j.chiabu.2015.10.024

Mascarenhas, M. D. M., Malta, D. C., Silva, M. M. A., Lima, C. M., Carvalho, M. G. O., \& Oliveira, V. L. A. (2010). Violência contra a criança: Revelando o perfil dos atendimentos em serviços de emergência, Brasil, 2006 e 2007. Cadernos de Saúde Pública, 26(2), 347-357.

Miranda, D. B. (2010). A caracterização do abuso sexual intrafamiliar de crianças no Distrito Federal, um olhar sobre as desigualdades (Unpublished master's thesis). Departamento de Serviço Social, Universidade de Brasília, Brasília.

O'Leary, P., Easton, S. D., \& Gould, N. (2017). The effect of child sexual abuse on men: Toward a male sensitive measure. Journal of Interpersonal Violence, 32(3), 1-23. doi: $10.1177 / 0886260515586362$

Pincolini, A. M. F., \& Hutz, C. S. (2014). Abusadores sexuais adultos e adolescentes no sul do Brasil: Pesquisa em denúncias e sentenças judiciais. Temas em Psicologia, 22(2), 301-311. http://dx.doi.org/10.9788/TP2014.2-03

Pinho, A. R. (2012). O atendimento a famílias em situação de abuso sexual: um estudo exploratório (Dissertação de Mestrado). Universidade de Brasília, Brasília, DF.

Retrato da Infância e da Adolescência no Distrito Federal. (2012). Brasília: Codeplan. Retrieved from http://www.tjdft.jus.br/ cidadaos/infancia-e-juventude/publicacoes/publicacoes-1/ retrato-da-infancia-e-da-adolescencia-no-distrito-federal.

Rodgers, K. B., \& McGuire, J. K. (2012). Adolescent sexual risk and multiple contexts: Interpersonal violence, parenting, and poverty. Journal of Interpersonal Violence, 27(11), 2091-2107. doi: $10.1177 / 0886260511432148$.

Santos, S. S., \& Dell'Aglio, D. D (2008). Compreendendo as mães de crianças vítimas de abuso sexual: Ciclo de violência. Estudos de Psicologia, 25(4), 595-606.

Scrandis, D. A., \& Watt, M. (2014). Child sexual abuse in boys: Implications for primary care. The Journal for Nurse Practitioners, 10(9), 706-713. doi: 10.1016/j. nurpra.2014.07.021

Serafim, A. P., Saffi, F., Achá, M. F. F., \& Barros, D. M. (2011). Dados demográficos, psicológicos e comportamentais de crianças e adolescentes vítimas de abuso sexual. Revista de Psiquiatria Clínica, 38(4), 143-147.

Setubal, C. B., Wolff, L. S., Stroher, L. M. C., Blanco-Vieira, T., \& Costa, L. F. (2019). "Não pode ser abuso... eu sou a mãe": Ofensa sexual materna. Revista de Psicología, 28(1). doi:10.5354/0719-0581.2019.53956

Spilbury, J. C., \& Korbin, J. E. (2013). Social networks and informal social support in protecting children from abuse and neglect. Child Abuse \& Neglect, 37S, 8-16. doi: 10.1016/j. chiabu.2013.10.027

Strickland, S. M. (2008). Female sexual offenders: Exploring issues of personality, trauma, and cognitive distortions. Journal of Interpersonal Violence, 23, 474-489. doi: 10.1177/0886260507312944 
Turner, A., Shattuck, A., Finkelhor, D., \& Hamby, S. (2016). Polyvictimization and Youth Violence Exposure Across Contexts. Journal of Adolescent Health, 58, 208-214. doi: 10.1016/j.jadohe.alth.2015.09.021

Valente, S. M. (2005). Sexual abuse of boys. Journal of Child and Adolescent Psychiatric Nursing, 18(1), 10-16. doi: 10.1111/j.1744-6171.2005.00005.x

Vara da Infância e da Juventude do DF (VIJ/DF) (2009). Centro de referência em violência sexual - CEREVS. Dados Consolidados - Ano 2009. Retrieved from http://www.tjdft. jus.br/cidadaos/infancia-e-juventude/estatisticas/ano-de-2009/ criancas-e-adolescentes-em-situacao-de-violencia-sexual
Vara da Infância e Juventude do Distrito Federal. (2010). Retrieved from http://tj-df.jusbrasil.com.br/noticias/2591362/1-vijdivulga-estatistica-sobre-violencia-sexual.

Willis, G. M., \& Levenson, J. S. (2016). The relationship between childhood adversity and adult psychosocial outcomes in females who have sexually offended: Implications for treatment. Journal of Sexual Aggression, 22(3), 355-367. https://doi.org/10.1080/13552600. 2015.1131341

Worley, K. B., Church, J. K., \& Clemmons, J. C. (2011). Parents of adolescents who have committed sexual offenses: Characteristics, challenges, and interventions. Clinical Child Psychology and Psychiatry, 17, 433-448. doi: 10.1177/1359104511417787 


\section{ERRATUM}

Regarding the article "Boy sexual victimization: Characteristics of family configuration and of the offender", with DOI number: http://dx.doi.org/10.1590/0102.3772e35428, published in Psicologia: Teoria \& Pesquisa, vol 35, elocation e35428:

\section{Page 1, Where was written:}

Lúcia Cavalcanti de Albuquerque Willians

Now read:

Lúcia Cavalcanti de Albuquerque Williams 